\title{
Chronology of Japanese Religion
}

\author{
Pre-Ceramic Period \\ Jōmon Period (ca. 2500 в.C- 250 в.C.) \\ Yayoi Period (ca. 250 B.C.-A.D. 250) \\ A.D. 57 Japanese envoy from the State of Nu pays tribute to the \\ Han court in China \\ 239 Envoy of Queen Himiko dispatched to the Wei court in \\ China
}

Kofun ("Tumulus") Period (ca. 250-550)

369 Japanese forces occupy southern tip of Korea

Asuka Period (ca. 550-710)

538 (or 552) Official introduction of Buddhism from the Packche court in Korea to the Yamato court

562 Kingdom of Silla (Shilla) destroys Mimana, Japan's foothold in Korea

$589 \quad$ Unification of China by the Sui dynasty

593-621 Regency of Prince Shōtoku (573-621)

604 Seventeen-Article Constitution proclaimed

618 Establishment of T'ang dynasty in China

645 Taika Reform begins

701-702 Taihō Reform Code promulgated

Nara Period (710-781)

710 Establishment of the first permanent capital, Heijō-kyō, at Nara

712 The Kojiki (Records of Ancient Mattcrs) compiled

720 The Nibongi (Chronicles of Japan) compiled

735 Unification of Korea under Kingdom of Silla

752 Dedication of the Great Buddha statue at Tōdai-ji in Nara

Heian Period (781-1191)

794 Establishment of the second permanent capital, Heian-kyō, at Kyoto

805 Saichö (767-822) returns from China and founds the Tendai Buddhist School

$806 \quad$ Kūkai (774-835) returns from China and founds the Shingon Buddhist School

815 New compilation of the Register of Families (Shinsen shōjiroku) completed 


\section{CHRONOLOGY}

822

Ordination hall (kaidan) established at Mount Hi'ei

847

Ennin (792-862) popularizes Tendai Esoterism (Tai-mitsu)

858

Beginning of de facto rule by the Fujiwara oligarchy

(Fujiwara regency)

$907 \quad$ End of the T'ang dynasty in China

927

960

Institutes of the Engi Era (Engi-shiki) completed

1017

1086

Death of Genshin (b. 942), author of Essentials of Salvation

$(\tilde{O} j \bar{o} y \bar{o} s h \bar{u})$

1132 Death of Ryōnin (b. 1071), forerunner of Pure Land

Buddhism in Japan

1156 The Hogen no Ran insurrection, led by ex-Emperor Sutoku and others

1175

1191

Hōnen (1133-1212) founds the Pure Land (Jōdo) sect

Yōsai (or Eisai, 1141-1215) introduces the Rinzai

(Lin-chi) School of Zen

Kamakura Period (1192-1333)

1192 Minamoto Yoritomo establishes the Kamakura bakufu or shogunate

1205 Hōjō Yoshitoki becomes shogun's regent; beginning of Hōjō regency in Kamakura shogunate

1220

1222

The Gukanshō (a Buddhist philosophy of history) written

1224 Kamakura regime banishes three retired monarchs (Go-Toba, Tsuchimikado, and Juntoku) from the capital

1227 Shin or Ikkó) sect

1227

1238

Dōgen (1200-1253) introduces Sōtō (Ts'ao-tung) Zen

1253 Nichiren (1222-1282)

Great statue of Amida Buddha constructed at Kamakura

1274 First Mongol invasion

1275 Ippen (1239-1289) founds the Ji ("Time") sect

1281 Second Mongol invasion

1333 End of the Kamakura shogunate

Ashikaga (or Muromachi) Period (1338-1573)

1338

1339

1368

Beginning of the Ashikaga shogunate

The Jinno-shōto-ki (Records of the Legitimate Succession of the

Divine Sovereigns) by Kitabatake Chikafusa (1293-1354) completed

1392

End of the Mongol (Yuan) dynasty and establishment of the Ming dynasty in China

1401 Establishment of the Yi dynasty in Korea

Ashikaga shogunate requests diplomatic relations with the Ming court 
1443 Death of Zeami (b. 1363), master of the $N \bar{o}$ drama

1467 Beginning of the Ōnin War; beginning of nationwide civil wars

1477 End of the Ōnin War

1479 Rennyo (1415-1499) builds the Hongan-ji, the main temple of the True Pure Land or Ikkō sect, at Yamashina

1511 Death of Yoshida Kanetomo (b. 1435), advocate of Yuiitsu Shinto

1532 Armed conflicts between the Nichiren and the Ikko sects

1541 Oda Nobunaga (1534-1582), strongman of Japan, helps rebuild the Grand Shrine of Ise

1542 or 1543 Portuguese merchants arrive at Kyushu

1549 Francis Xavier (1506-1552) arrives at Kagoshima

1551 Xavier leaves Japan; Roman Catholic (Kirishitan) activities continuc

1571 Oda Nobunaga's forces attack Mount Hi'ei monastic center

1573 End of the Ashikaga shogunate

Azuchi-Momoyama Period (1574-1600)

1582 Death of Oda Nobunaga; Toyotomi Hideyoshi (1536-

1598) succeeds to power

1587 First persecution of Kirishitan (Roman Catholic) faithful

$1592 \quad$ Hideyoshi's first Korean expedition

$1597 \quad$ Hideyoshi's second Korean expedition

1598 Death of Hideyoshi; Tokugawa Iyeyasu (1542-1616) rises to power

Tokugawa Period (1600-1867)

1603 Tokugawa Iyeyasu establishes the Tokugawa shogunate in Edo (Tokyo)

1608 Hayashi Razan (1583-1657) appointed Confucian tutor to shogun

$1614 \quad$ Anti-Kirishitan edict issued

1615 Buke Shohatto (Ordinances for the Military Houses) issued

1619 Death of Fujiwara Seika (b. 1561), noted Confucianist

$1624 \quad$ Spaniards expelled from Japan

1637-1638 The so-called Kirishitan uprising in Shimabara, Kyushu

1639-1640 Portuguese and other Europeans expelled from Japan

1641 National exclusion (sakoku) begins; only Dutch allowed to remain, but are restricted to Nagasaki

1648 Death of Nakaya Tōju (b. 1608), noted Confucianist

1654 Chinese Zen master Ingen (Tin-yüan, 1592-1673) establishes the Öbaku sect of Zen Buddhism in Japan

1657 Dai-Nihon-shi (History of Great Japan) commenced

1661 Manchu dynasty established in China

1682 Death of Yamazaki Ansai (b. 1618), scholar of the Chu Hsi School 
1685 Death of Yamaga Sokō (b. 1622), advocate of Bushi-dō

1688-1703 Genroku period, known for exuberance in novels, plays, poems, and paintings

1690 Death of Deguchi (Watarai) Nobuyoshi (b. 1614), Shinto theorist; Confucian temple moved to Yushima section of Edo

1691 Hayashi Hōkō (1644-1732) named hereditary head of the state (Confucian) university; Kumazawa Banzan (b. 1644), Confucian reformer, dies

1694 Death of Matsuo Bashō (b. 1644), Zen master; death of Yoshikawa Koretaru (b. 1615), Shinto theorist

1701 Death of Keichū (b. 1640), Buddhist priest and pioneer in National Learning Incident of the forty-seven ronin Death of Itō Jinsai (b. 1627), Confucian scholar Arrival of Giovanni Battista Sidotti (1668-1715), Italian priest

1709 Arai Hakuseki (1657-1725) appointed Confucian consultant to shogun

Death of Kaibara Ekken (b. 1630), Confucian scholar.

Muro Kyūsō (1688-1734) appointed Confucian consultant to shogun

1728

Death of Ogyū Sorai (b. 1666), Confucian scholar

1736

1744 Death of Kada Azumamaro (b. 1669), advocate of National Learning; death of Itō Tōgai (b. 1670), Confucian scholar Death of Ishida Baigan (b. 1685), founder of the Shingaku movement Death of Tominaga Nakamoto (b. 1715), rationalist philosopher Sugita Gempaku (1733-1817) studies Dutch surgery Death of Rinzai Zen master, Hakuin (b. 1685) Death of Kamo Mabuchi (b. 1697), Neo-Shintoist Dutch book, Tavel Anatomia, translated into Japanese Hiraga Gennai (1728-1779) produces frictional electricity machine

1789 Death of Miura Baien (b. 1723), rationalist philosopher 1790 Edict suppressing heterodox learning issued; Chu Hsi school (Shushi-gaku) precepts become official dogma

$1795 \quad$ Ban issued against both the Fuji-kō, a devotional association of Mount Fuji, and the principle of Fuju-fuse ("not receiving from outsiders") of Nichiren Buddhism Motoori Norinaga (1730-1801) completes the Kojiki-den (Commentary on the "Kojiki") Shogunate issues edict to destroy foreign ships 
Fukuoka Mitsugu and other Christians executed

1843

Death of Hirata Atsutane (b. 1776), a Neo-Shintoist

1850

Death of Kurozumi Munetada (b. 1780), founder of the

Kurozumi-kyō

1853 First mission of Commodore Matthew Perry to Japan

1854 Perry returns; treaty between Japan and United States concluded

1855 Shogunate establishes School of Western Learning

( Togaku-sho)

1856 Townsend Harris (1804-1878), first American consulgeneral, arrives; death of Ninomiya Sontoku (b. 1787), religious reformer

1865

Fukuzawa Yukichi (1834-1901) founds a private school later named the Keiō Gijuku

Meiji Synthesis (1867-1945)

Meiji Era (1867-1912)

1868 Charter Oath proclaimed; capital moved to Edo, renamed Tokyo; Separation Edict of Shinto and Buddhism (ShinButsu Hanzen-rei) issued; Department of Shinto reestablished

1871 The haibutsu kishaku ("exterminate Buddhism") movement reaches its climax

1872 Conscription ordinance issued; edict issued that permits Buddhist priests to eat meat, to marry officially, to grow hair, and to take on a family name, but begging for food (takuhatsu) no longer allowed

1873 Edict against Christianity remaining from Tokugawa regime removed; edict permitting Buddhist nuns to cat meat and to grow hair issued

1875 Niijima Jō (1843-1890) founds a Christian school, called Dōshisha, in Kyoto

1876 Sundays declared holidays; Kasahara Kenju and Nanjö Bunyū begin studies under F. Max Müller

1877 Tokyo Imperial University established

1878 Ernest Fenollosa (1853-1908) appointed teacher

1881 1872 edict prohibiting begging rescinded

1882 Tokyo Semmon Gakkō (later renamed Waseda Univcrsity) established

$1884 \quad$ Yayoi period pottery discovered

1889 Constitution permitting a measure of religious freedom adopted

$1890 \quad$ Imperial Rescript on Education promulgated

1893 Japanese delegates attend the World's Parliament of Religions in Chicago

1894-1895 Sino-Japanese War 
$1898 \quad$ Hawaii annexed to United States

$1899 \quad$ Extra-territorialities eliminated

1902 Anglo-Japanese alliance concluded

1904-1905 Russo-Japanese War

1909 D. T. Suzuki (1870-1960) returns from the United States

$1910 \quad$ Annexation of Korea

1912 Republican government established in China

Taishō Era (1912-1926)

1914-1918 World War I

1915 Japan presents the Twenty-One Demands to China

$1920 \quad$ First May Day celebrated

1924 Quota Act ends Japanese immigration to United States

Shōwa Era (1926-)

$1931 \quad$ Manchurian incident

1933 Japan withdraws from the League of Nations

1937 Beginning of Japan's war on China

1939-1945 World War II

$1940 \quad$ Rome-Berlin-Tokyo axis concluded

Postwar Period (1945-)

1945 General Douglas MacArthur appointed Supreme

Commander of the Allied Powers (SCAP); State Shinto

disestablished; death of Kitarō Nishida (b. 1870), religious philosopher

1946 New constitution promulgated; religious liberty assured; Emperor renounces his divinity; establishment of Jinja honchō; renewal of the Sōka Gakkai, Ōmoto-kyō, Honmichi, PL Kyōdan, and other "new religions"

1947 New constitution goes into effect; renewal of World Messianity (Sekai Kyūsei-kyō)

$1950 \quad$ Korean War begins

1951 Matthew Ridgeway succeeds MacArthur as SCAP; San

Francisco Peace Conference; formation of Association of

New Religions (Shin-Shü-ren); Religious Persons Law

(Shükȳo-höjin-hō) issued

1952

Second World Buddhist Conference held in Tokyo

1955

Bandung Conference of Asian and African nations held

1961 World Religionists' Peace Conference held in Kyoto

1962 Death of Hajime Tanabe (b. 1885), religious philosopher

1964

1965

Komeito (political wing of the Söka Gakkai) formed

1966

Second Vatican Council advocates religious liberty

Cultural Revolution begins in China; National Foundation

Day (Februaryll) restored 
1972 Sun Myung Moon's Unification Church begins activities in Japan; President Richard Nixon visits China; Okinawa returned to Japan; Twelfth World Buddhist Conference held in Japan

1973 United States withdraws from Vietnam

$1974 \quad$ Richard Nixon resigns American presidency

1976 Death of Mao Tse-tung (b. 1893) in China

$1981 \quad$ First papal visit to Japan

1985 Prime Minister Y. Nakasone pays official visit to Yasukuni Shrine (Shinto shrine for soldiers killed in wars) 
